\title{
Intermediation Cost and Non-Performing Financing: A Case Study of Pakistan

\author{
Azam Ali*
}

\begin{abstract}
The instinct of bankers is to keep the borrowers alive through recycling and renewals of bad loans into loans, a window dressing exercise; or worse yet, advancing additional fresh loans to effectively insolvent borrowers to tide over what is perceived as cash flow problems and forthcoming illiquidity, thereby getting deeper into financial distress. In this sense, insolvency occurs first, illiquidity follows later. Increase in the intermediation costs lead to increase in Non-performing Loans (NPLS). The intermediation cost reflects the operating efficiency of banks. If credit risk is not managed properly it eventually shows up in NPLS, or the concentration of banking credit in a few sectors of the economy, or in a few segment of borrowers, or a rising proportion of riskier loans in its portfolio during times of rapid expansion of banking credit. This paper studies intermediation costs in credit markets within a dynamic Stiglitz and Weiss (1981) framework. The theoretical predictions of our model gains support by Pakistani banks' quarterly data for the period 2007-09. Data suggests that an increase in intermediation costs results in an increase in NPLs. Analyses show that, if intermediation cost is administered properly, it ultimately lowers NPLs. We argue that minimization of intermediation costs improves financial soundness.
\end{abstract}

Keywords: Credit market, borrower, bad loans, financial distress, insolvency, credit risk, non-performing loans.

\section{Introduction}

Generally, it is but natural for bankers to keep the borrowers alive through recycling and renewals of bad loans into loans which in essence is a window dressing exercise; or worse still, advancing additional fresh loans to effectively insolvent borrowers to tide over what is perceived as cash flow problems and imminent illiquidity, thereby getting deeper into financial distress. In this sense, insolvency occurs first, illiquidity follows later. The borrowers are already in deep distress by then, and they are well past the stage of routine rescue operations because their illiquidity originates not from their routine business turnover and cash flows, but rather from structural weaknesses in their operations. The same occurred in the nationalized banking era in Pakistan when banks kept bailing out insolvent PSEs, lending more intentionally because of collusion or bad judgment, or on government directives, then writing off the loans while the banking supervision outfit was alive to these perils (BSR, 2008).

Figure-01: Non-Performing Financings/Gross Financings

The intermediation cost is not a CAMEL indictor, but it reflects the operating efficiency of banks though only on the funding side since it is the ratio of administrative expenses to the average amount of deposits and borrowings of a financial institution. BSR estimates show that intermediation costs during the late 1990s was about $3.5 \%$, and then began to decline and is currently around $2.7 \%$. This suggests that banking efficiency improved at least on the funding side over the late reform period, but still it is above the cost range prevailing in

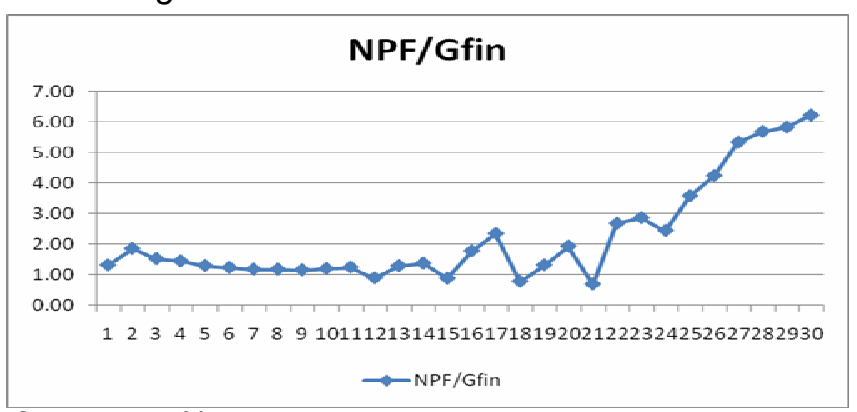
comparator countries at around $2.0 \%$, and is much higher than the range of 1.5 to $2.0 \%$ observed in leading countries.

These intermediation costs are exclusive of provisioning costs for NPFs. Provisioning for NPFs ads close to one percent to banking intermediation costs over and above the level of $2.7 \%$. This is a major reason for high intermediation costs, especially for the recently privatized large banks. Part of the cost of provisioning and equity replenishments have been assimilated and recycled into the balance sheets of financial institutions thereby raising the costs of operations and thus intermediation costs, which refuse to be compressed beyond current levels.

\footnotetext{
*Azam Ali is Junior Joint Director in Statistics \& DWH Department, State Bank of Pakistan, azam.ali@sbp.org.pk The views presented in the study are of the author and do not represent that of his organization. The author is solely responsible for any error or omission.
} 
BSR further explains that banking spreads have remained around $7 \%$ during most of the 1990s and have remained around the same over the recent period, even higher, at around $8 \%$. This is not surprising because structural changes in the credit system occurred concurrently to significant volatility, both in the deposit rates and lending rates over the reform period. The concern that banking spreads are high is valid, but in a deregulated system there is hardly much that the monetary authority (SBP) can do to help reduce the spread since it is embedded into the bank funding structure on the one side, and into lending operations and investments on the other.

\subsection{Background of the Study}

The financial system in Pakistan has evolved over the years in response to growth of the economy and government plans for the development of the country. The system comprised the Central Bank [State Bank of Pakistan (SBP)], Commercial Banks, Microfinance Banks, Specialized Banks, and a mix of Non-Bank Financial Institutions (NBFls) including Development Financial Institutions (DFIs), Investment Banks, housing finance companies, leasing companies, modarabas and mutual funds, brokerage houses and insurance companies. Three Stock Exchanges at Karachi, Lahore and Islamabad are also a part of Financial System in Pakistan. In addition to managing the monetary policy, SBP also regulates banks and DFls. Securities and Exchange Commission of Pakistan (SECP) supervises few from a mix of Non-Bank Financial Institutions (NBFls) which include investment banks, leasing companies, insurance companies, modarbas and mutual funds. Pakistan's banking sector is made up of 53 banks of which 36 are commercial banks (including six full fledge Islamic Banks), four specialized banks, seven development financial institutions and six micro-finance banks. The total assets of the Islamic banking industry in Pakistan are over Rs. 313 billion as of 30th June 2009 which accounts for a market share of $5.2 \%$ of total banking industry assets. Based on the factors like unmet demand, geographical coverage, product development, new segments and data collected by different Islamic banks, it is estimated that total assets of Islamic banking industry will reach over one trillion rupees up to year 2012 (SBP Review, 2009).

Islamic Banking today is an industry that is still evolving. The growth of Islamic Banking is a result of economic growth in the Islamic world. Islamic Banks around the world have devised many financial products based on the risk-sharing and profit-sharing principles of Islamic Banking. For day to day Banking activities, a number of financial instruments have been developed that satisfy the Islamic doctrine and provide acceptable financial returns for investors. Broadly speaking, the areas in which Islamic Banks are most active are in trade and commodity finance and leasing.

Some countries endorse special laws for Islamic Banking to organize the operations of Islamic Banks and their relations with the central bank. Islamic banks are also exposed to credit risk. It is a counter-party risk inherent in some modes of Islamic finance. Exposure to such risk is increased by the absence of well developed credit risk assessment systems and associated expertise for Islamic banks. The central bank develops and implements rules that ensure the health of the financial conditions of the Islamic Banks. It enforces a number of mandatory

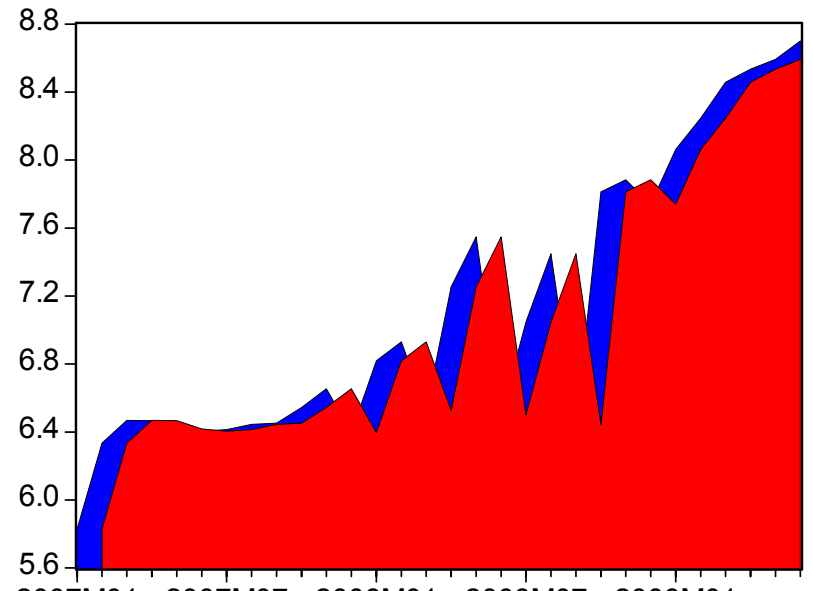
2007M01 2007M07 2008M01 2008M07 2009M01

financial ratios and rules and increases administrative cost. The increasing global interest in Islamic Banking is due to a phenomenal and rapid growth of Islamic finance in the Islamic countries as well as other parts of the world during the past two decades. Major international Islamic Banks, Conventional Banks through their Islamic branches/special windows and specialized financial institutions offer Islamic products catering to growing Muslim presence in these markets.

Islamic Financial institutions are very well developed to be able to offer various borrowing instruments. The composition of financing by Islamic banks is different from their counterparts' conventional banks' loans/advances. Islamic banks float major amount against Murabaha financing (around 36\%) followed by ljarah (around 23\%) and Diminishing Musharaka financings (around 15\%). Therefore, with severe competition in the sector they are in a position to offer the least costly instruments to attract borrowers provided they control their administrative expenses. The intermediation cost reflects the operating efficiency of banks. Increase in the intermediation costs leading to increase in Non-performing Financing.

Financial intermediation is understandably costly. The costs arise from asymmetric information between the lender and the borrower. The choice of the project by the borrower can only be known with a noise by the lender, therefore it is natural for the lender to require a risk premium for the borrower to pay. Higher willingness to pay for risk premium leads to an increase in the frequency of choices of riskier projects which may even lead to credit rationing (Stiglitz and Weiss, 1981). Another line of 
literature relies on the costly monitoring process. In the case of default, the lender must pay monitoring costs to repatriate assets, (Townsend, 1979).

\subsection{Problem Statement}

The intermediation cost reflects the operating efficiency of conventional banks though only on the funding side since it is the ratio of administrative expenses to the average amount of deposits and borrowings of a financial institution. The immediate impact of increasing intermediation costs is the worsening of the financial position of the borrower. This increase also worsens the financial position of the Bank. Islamic Financial institutions are very well developed to be able to offer various borrowing instruments. Therefore, with severe competition in the sector they can offer the least costly instruments to attract borrowers. The question arises to address, 'do Islamic banks operating in Pakistan reveal the same end result of intermediation cost on their Non Performing Financing (NPFs)?

\subsection{Study objective}

As the intermediation cost reflects the operating efficiency of banks and increase in the intermediation costs leading to increase in NPFs of banks, we are motivated to study the impact of intermediation costs on NPFs in credit markets with special focus on Islamic banks operating in Pakistan. We do analyze, 'do increase in the transaction costs of Islamic Banks lead to an increase in their NPFs'? For this, we decompose the mark up rate into intermediation cost and the rate of return. The rate of return then will control the change in the pool of risky projects by changes in the mark up rates. We use 'Spread' variable to control this latter effect.

\section{Literature Review}

According to dynamic framework set by Stiglitz and Weiss (1981), or a given interest rate $r$, there is a critical value $\theta$ such that a firm borrows from the bank if and only if $\theta>\theta^{\prime}$. This follows immediately upon observing that profits are a convex function of $R$. Hence expected profits increase with risk. Our argument that the adverse selection of interest rates could cause the returns to the bank to decrease with increasing interest rates hinged on the conjecture that as the interest rate increased, the mix of applicants became worse. As the interest rate increases, the critical value of $\theta$, below which individuals do not apply for loans, increases. The expected return on a loan to a bank is a decreasing function of the riskiness of the loan. These imply that, in addition to the usual direct effect of increases in the interest rate increasing a bank's return, there is an indirect, adverseselection effect acting in the opposite direction.

We now show that this adverse-selection effect may outweigh the direct effect. To see this most simply, assume there are two groups; the "safe" group will borrow only at interest rates below $r$,, the "risky" group below $r 2$, and $r,<r 2$. When the interest rate is raised slightly above $r$, the mix of applicants' changes dramatically: all low risk applicants withdraw.

Cafer and Ferhan (2008), analyzed that, intermediation is costly due to asymmetric information and implies greater volatility in business cycle. They applied Stiglitz and Weiss framework on Turkish data for 19912004 period. They conclude that an increase in intermediation costs results in an increase in non-performing loans and an increase in foreign financing due to shrinking of domestic credit markets. They claim that they answered two major questions absent in the empirical literature of financial fragility. One is the link between greater financial fragility and intermediation costs and the second is the shrinking domestic credit markets as a result of these distortions.

İmrohoroğlu and Kumar (2004) modify the standard neoclassical model by incorporating financial intermediation in order to deliver returns consistent with the observation that capital primarily flows to middle income countries. They built a static contracting framework, where costly intermediation together with an adverse selection problem, have quantitatively important effects on capital flows. They maintained that
Empirical CDF
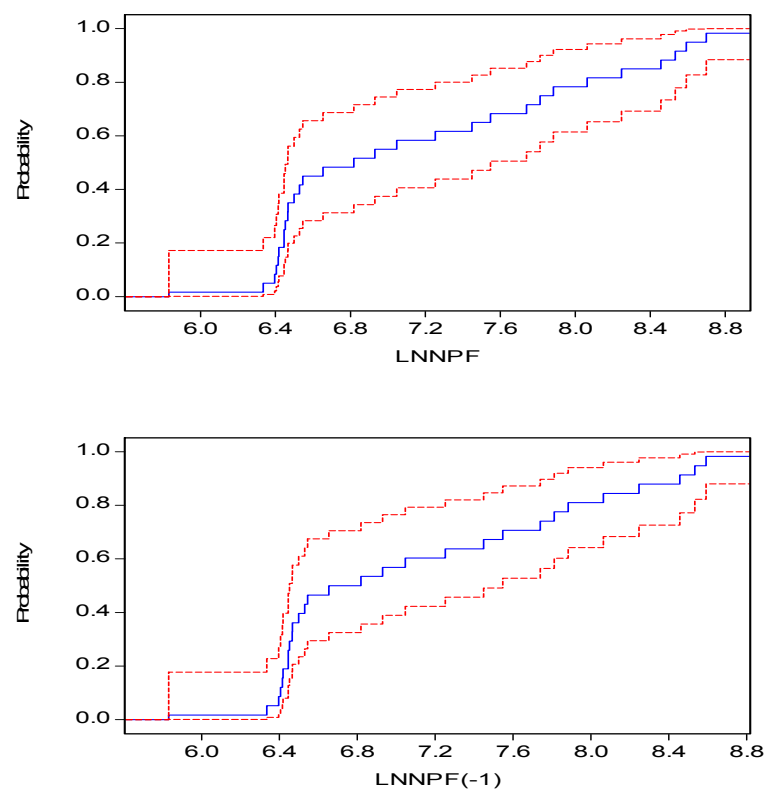
when intermediation costs are ignored, the model behaves like the neoclassical model in terms of capital returns. However, when intermediation costs are considered, returns to capital in middle income countries could exceed those in poor and rich countries-high costs of intermediation cause poor countries to concentrate their investments in projects with low returns, while the standard neoclassical effect lowers returns in capital-rich countries.

Fadzlan and Majid (2008) investigated the performance of Malaysian Islamic banking sector during the period of 2001-2005. They evaluated several efficiency estimates of individual banks using nonparametric Data Envelopment Analysis (DEA). The analysis linked the variation in calculated efficiencies to a set of variables, i.e. bank size, ownership, capital, non-performing loans and management quality. They suggested that during the period of study, scale inefficiency dominates pure technical inefficiency in the Malaysian Islamic banking sector. They found that foreign banks have exhibited higher technical efficiency compared to its domestic peers. The second stage empirical results based on multivariate Tobit model also suggested that technically more efficient banks are larger, have greater loans intensity, and on average have less non-performing loans.

\section{Research Methodology}

\subsection{Model Specifications}

Non-Performing Financings (NPFs) is a good candidate for proxying the total transactions of Islamic Banks that default (Figure-1). We can represent this relationship below:

$$
\mathrm{NPF}_{\mathrm{t}+1}=\omega(\lambda \mathrm{t})
$$

Therefore the assumption implies $\omega^{\prime}(\lambda)>0$. Equation describes a possible non-linear relationship between NPF and $\lambda$. An increase in risky projects leads to the increase in projects under default a period later. The model prediction is that increase in the transaction costs leading to an increase in NPFs. We can test this hypothesis with the following linear regression. The only possible problem with this regression is to obtain an unbiased estimator. We have to decompose the markup rate into intermediation costs and the rate of return. The rate of return then will control of the change in the pool of risky projects by changes in the markup rates. We use spread variable to control for this latter effect. This variable is the difference between the deposit and financing rates. If the model is true the coefficient ' $y$ ' in which is the parameter for intermediation costs has to be positive. Moreover, it will be unbiased. The results are presented in Table (4). As expected we find a positive and significant $Y$ coefficient. We have following model with little modifications:

$$
N P F_{t}=c+\alpha N P F_{t-1}+\Phi \text { Spread }_{t-1}+\gamma T_{t-1}+\mu_{t}
$$

Where $\alpha, \Phi$ and $y$ are coefficients. $N P F_{t}$ is Non Performing Financing in time $t, N P F_{t-1}$ is Non Performing Financing, $T_{t-1}$ is intermediation cost and Spread $_{\mathrm{t}-1}$ is the difference between the deposits and financing rates in a later period.

\subsection{Data Sources}

The data collected are from six full fledged Islamic Banks operating in Pakistan and from Islamic Banking Department, Statistics \& DWH Department, and Banking Surveillance Department of State Bank of Pakistan to supplement the information. Different financial reports were also considered to have accurate picture of the intermediation cost, spread and non-performing financings of Islamic Banks.

\section{Analysis}

\subsection{Unit Root Tests}

To test the stationarity of the data, we applied unit root test on all variables i.e. both exogenous variables and endogenous variables. We checked the stationarity of these variables and removed the non-stationarity of the data. All three variables have $\mathrm{i}$ (1) order and passed the co-integration and power tests.

Table: 01 Non-Performing Financings (NPFs) Where LnNPF=LOG (NPFs)

\begin{tabular}{|l|l|l|l|l|l|l|l|}
\hline $\begin{array}{l}\text { t-statistics in (and ) at } \\
95 \% \text { level of significance }\end{array}$ & $\begin{array}{l}\text { With } \\
\text { Constant }\end{array}$ & $\begin{array}{l}\text { Without } \\
\text { Constan } \\
\mathbf{t}\end{array}$ & lag & Trend & lag \\
\hline
\end{tabular}




\begin{tabular}{|l|l|l|l|l|l|l|}
\hline Level & $\begin{array}{l}1.3973 \\
(-2.9763)\end{array}$ & 2 & $\begin{array}{l}3.4801 \\
(-1.9539)\end{array}$ & 2 & $\begin{array}{l}-0.8463 \\
(-3.5875)\end{array}$ & 2 \\
\hline 1st Difference* $^{*}$ & $\begin{array}{l}-5.4534 \\
(-2.8813)\end{array}$ & 1 & $\begin{array}{l}-2.8823 \\
(-1.9432)\end{array}$ & 2 & $\begin{array}{l}-5.4382 \\
(-3.4409)\end{array}$ & 1 \\
\hline
\end{tabular}

${ }^{*}$ The log of NPFs could not pass the unit root test at level, while at first difference, it has passed the test.

The test of stationarity of Non-performing Financing data series shows that it does not have stationary data at level while got tested with different combinations of testing with constant, without constant and trend, and consequently we realized that it has some outliers. To remove the hindrances in data, we checked its stationarity at first difference with the same three combinations as done with level and found that it has stationary at level. We know that to have a balanced model, all the variables should have same order. To come up to this, we tested the remaining variables as below.

Table: 02 Burden (Intermediation Cost=T) WHERE LnT=LOG $(\mathrm{T})$

\begin{tabular}{|l|l|l|l|l|l|l|l|}
\hline $\begin{array}{l}\text { t-statistics in ( ) } \\
\text { 95\% level of significance }\end{array}$ & $\begin{array}{l}\text { With } \\
\text { Constant }\end{array}$ & lag & $\begin{array}{l}\text { Without } \\
\text { Constant }\end{array}$ & lag & Trend & lag \\
\hline Level & $\begin{array}{l}-3.6839 \\
(-2.9678)\end{array}$ & 0 & $\begin{array}{l}-0.8022 \\
(-1.9593)\end{array}$ & 0 & $\begin{array}{l}-4.1841 \\
(-3.5742)\end{array}$ & 0 \\
\hline & & & & & & \\
1st Difference* & -5.8879 & 1 & -5.9494 & 1 & -5.7869 & 1 \\
& $(-2.9763)$ & $(-1.9539)$ & 1 & $(-3.5875)$ & \\
\hline
\end{tabular}

${ }^{*}$ The log of T could not pass the unit root test at level, while at first difference, it has passed the test.

Again the test of stationarity of intermediation cost (burden) data series shows that it does not have stationary data at level while got tested with different combinations of tastings with constant, without constant and trend, and consequently we realized that it has some outliers. To remove the hindrances in data, we checked its stationarity at first difference with the same three combinations as done with level and found that it has stationary at level.

Table: 03 Spread (spread) WHERE LnSpread=LOG (spread)

\begin{tabular}{|l|l|l|l|l|l|l|}
\hline $\begin{array}{l}\text { t-statistics in (a) ( ) at } \\
\text { 95\% level of significance }\end{array}$ & $\begin{array}{l}\text { With } \\
\text { Constant }\end{array}$ & lag & $\begin{array}{l}\text { Without } \\
\text { Constant }\end{array}$ & lag & Trend & lag \\
\hline Level & $\begin{array}{l}-4.3569 \\
(-2.9678)\end{array}$ & 0 & $\begin{array}{l}-0.1438 \\
(-1.9529)\end{array}$ & 0 & $\begin{array}{l}-4.5412 \\
(-3.5742)\end{array}$ & 0 \\
\hline 1st Difference* & $\begin{array}{l}-7.1339 \\
(-2.9719)\end{array}$ & 0 & $\begin{array}{l}-7.2719 \\
(-1.9534)\end{array}$ & 0 & $\begin{array}{l}-6.9953 \\
(-3.5806)\end{array}$ & 0 \\
\hline
\end{tabular}

*The log of spread could not pass the unit root test at level, while at first difference, it has passed the test.

Finally, the test of stationarity of Spread data series shows that it also does not have stationary data at level while got tested with different combinations of tastings with constant, without constant and trend, and consequently we realized that it has some outliers. To remove the hindrances in data, we checked its stationarity at first difference with the same three combinations as done with level and found that it has stationary at level.

We now found that we have a balanced model, order ONE. The model is perfect to run on the data to have the results. 


\section{Empirical results}

To verify our assumption above, 'If the model is true the coefficient ' $\mathrm{y}$ ' in which is the parameter for intermediation costs has to be positive and it will be unbiased', we applied natural logarithm, ran regression on the following equation and found the results presented in Table-04.

$$
\operatorname{LnNPF}_{t}=c+\alpha \operatorname{LnNPF}_{\mathrm{t}-1}+\Phi \operatorname{LnSpread}_{\mathrm{t}-1}+\gamma \operatorname{LnT}_{\mathrm{t}-1}+\mu_{\mathrm{t}}
$$

As expected we found a positive coefficient of Burden ' $T$ ' (0.417) which shows that intermediation cost has positive relationship with NonPerforming Financings of Islamic Banks. Though values of the Rsquared and the adjusted R-squared were not very close to ' 1 ', the Durbin-Watson and probability values were favoring our results.

Figure-02: Non-Performing Financing and Burden

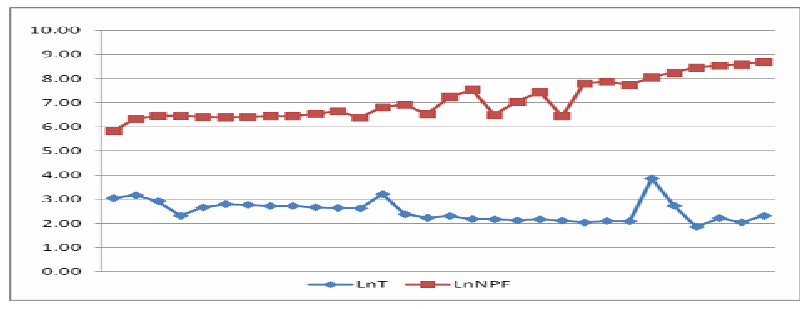

\section{Conclusion and Further Research}

Banks exist because they create liquidity and transform risk. Efficient risk management capacity is necessary to enable banks to strategically position themselves in the market. This paper examined the impact of intermediation cost on the NPFs of Islamic banks operating in Pakistan during January 2007 to June 2009. Study found a positive correlation between intermediation cost (Burden) and NPFs of Islamic banking industry. The analysis has shown that proper management of intermediation cost ultimately lowers administrative expenses and improves soundness of banking institutions.

Further research is proposed to compare the impact of intermediation cost of Conventional Bank's NPLs with NPFs of Islamic Banks operating in Asian-Pacific countries. 


\section{References}

Besci Z., P. Wang and M. A. Wynne, 1999, "Costly intermediation, the Big Push and the Big Crash", Journal of Development Economics, Vol. 59, pp. 275-293.

Cafer Kaplan and Ferhan Salman, 2008, "Intermediation Cost and Financial Fragility”, Research Department, Financial Research Division, Istiklal Cad., No. 10, Ankara

Cho, Yoon-Je, 1986, "Inefficiencies from Financial Liberalization in the Absence of Well-functioning Equity Markets" Journal of Money, Credit, and Banking Vol. 18 (May) pp. 191-9.

Fadzlan Sufian and Muhd-Zulkhibri Abdul Majid, (2008), "Bank Ownership, Characteristics, and Performance: A Comparative Analysis of Domestic and Foreign Islamic Banks in Malaysia J.KAU: Islamic Econ., Vol. 21, No. 2, pp. 337.

İmrohoroğlu A. and K. B. Kumar, 2004, "Intermediation Costs and Capital Flows," Review of Economic Dynamics, Academic Press for the Society for Economic Dynamics, vol. 7(3), pp. 586-612.

State Bank of Pakistan: SBP Review, 2009, various issues.

State Bank of Pakistan, Banking System Review (BSR), 2008, various issues

State Bank of Pakistan, Financial Sector Assessment, 2008, various issues

State Bank of Pakistan, (2009), Pakistan's Islamic banking Sector Review, Islamic banking Department, SBP, Karachi.

Stiglitz, J. and A. Weiss, (1981), "Credit Rationing in Markets with Imperfect Information', American Economic Review, LXXI, pp. 383-410

Townsend, R. M. (1979) "Optimal Contracts and Competitive Markets with Costly State Verification," Journal of Economic Theory, October, pp. 265-293. 


\section{Appendices}

Table-04: Intermediation Cost and Non-Performing Financings

\begin{tabular}{cccc} 
Variables & Coefficient & t-statistics & \\
\cline { 2 - 4 } C & 254.048 & 2.1327 & $(0.919)$ \\
& & & \\
DNPF $_{\mathrm{t}-1}$ & 0.1228 & 1.9943 & \\
& & $(0.7548)$ & \\
Burden $_{\mathrm{t}-1}$ & 0.417 & 2.6450 \\
& & $(0.226)$ & \\
Spread $_{\mathrm{t}-1}$ & 0.078 & 1.9451 & \\
& & & $(0.981)$ \\
No. of obs. & & 30 &
\end{tabular}

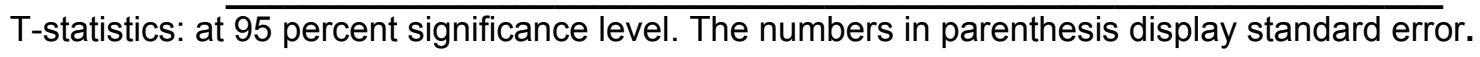

Figure-03: Non-Performing Financings and Spread

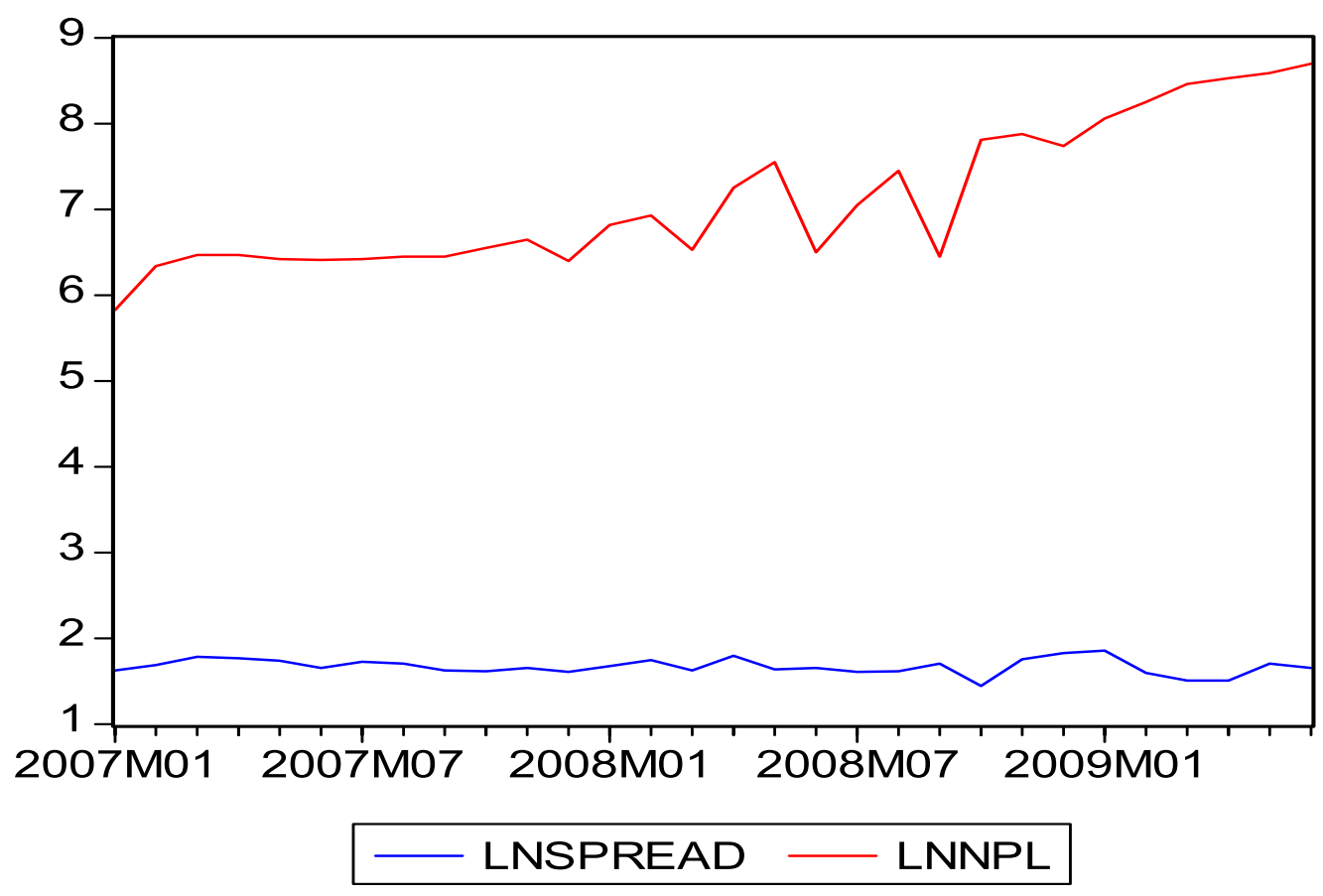


Figure-04: Burden and Spread

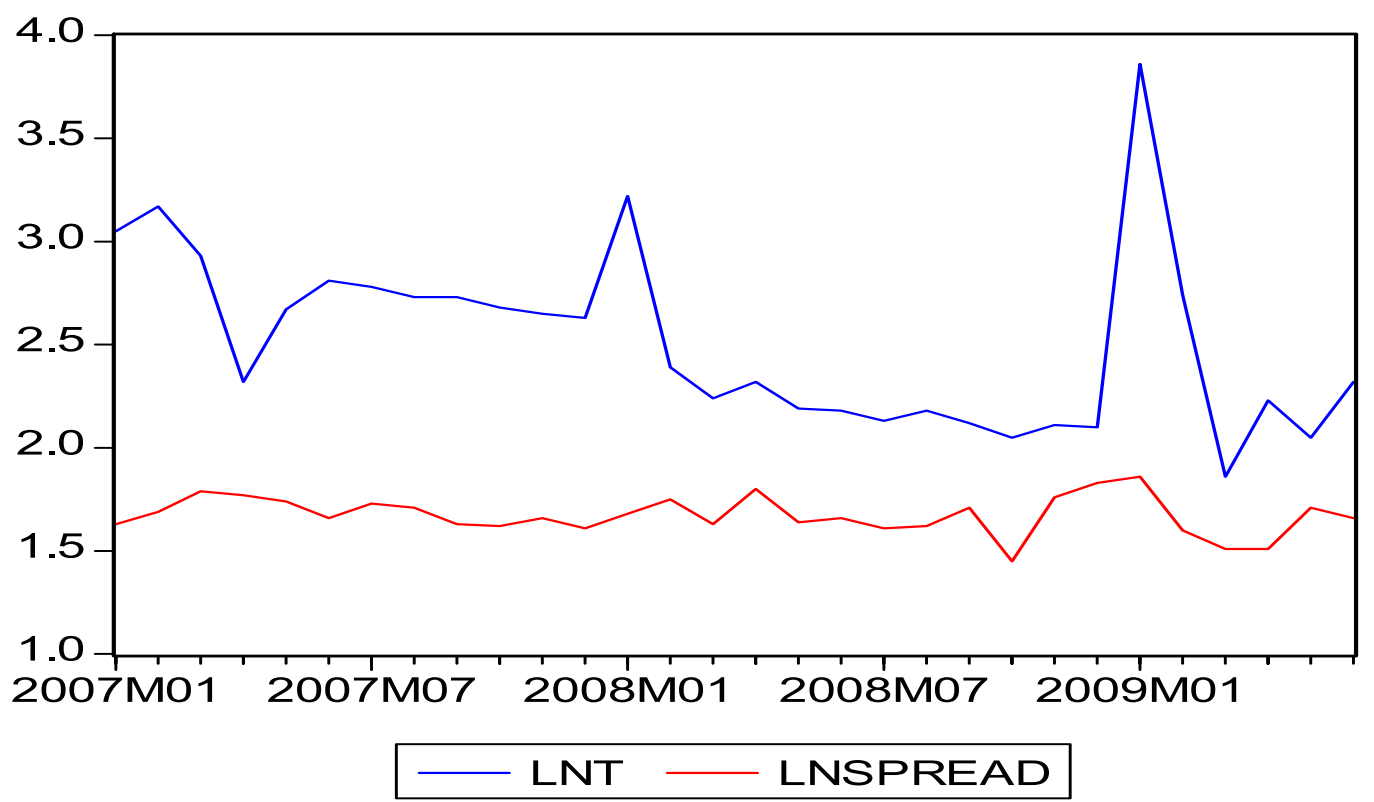

Figure-05: Non-Performing Financings, Burden and Spread

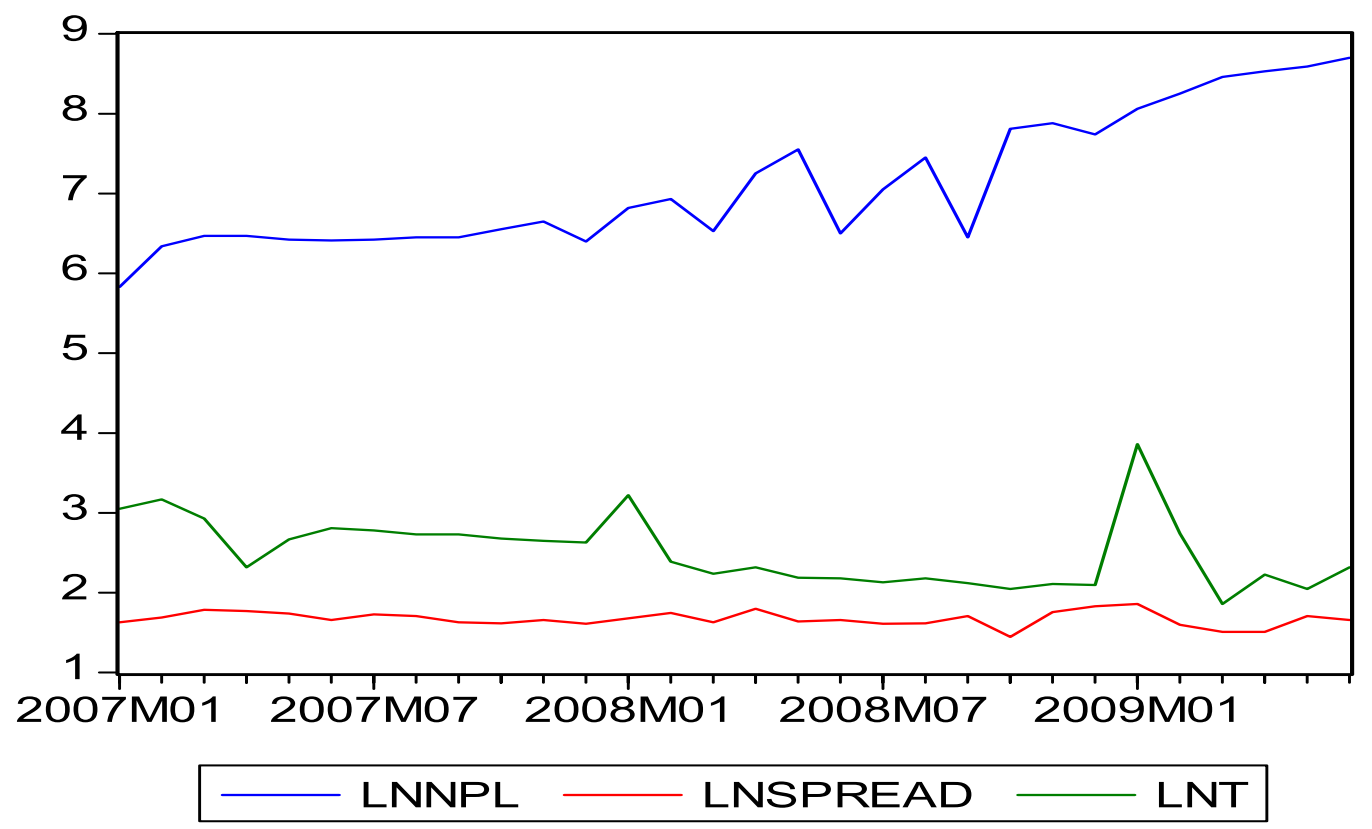




$$
\mathrm{NPL}_{t}=c+\mathrm{NPL}_{t-1}+\theta \operatorname{Spread}_{t-1}+\beta \mathrm{T}_{\mathrm{t}-1}+\mu_{t}
$$

\section{Correlogram of 'LnNPF'}

\section{At Level}

Date: 11/18/09 Time: 09:48

Sample: 2007M01 2009M06

Included observations: 30

\begin{tabular}{|c|c|c|c|c|c|}
\hline Autocorrelation & $\begin{array}{c}\text { Partial } \\
\text { Correlation }\end{array}$ & $A C$ & PAC & $\begin{array}{l}\text { Q- } \\
\text { Stat }\end{array}$ & Prob \\
\hline$\cdot||^{* * * \star *} \mid$ & $\left.\right|^{* * * * *} \mid$ & 10.634 & 0.634 & 13.316 & 0.000 \\
\hline$.\left.\right|^{* * *} \mid$ & $1^{*} .1$ & 20.449 & 0.079 & 20.239 & 0.000 \\
\hline$\left.\cdot\right|^{* * *} \mid$ & $1^{*} \cdot 1$ & 30.395 & 0.139 & 25.785 & 0.000 \\
\hline$\left.\right|^{* *} . \quad \mid$ & $.{ }^{* *} \mid$ & 40.203 & 0.190 & 27.303 & 0.000 \\
\hline$\left.\right|^{*} .1$ & & 50.188 & 0.136 & 28.658 & 0.000 \\
\hline$\left.\right|^{* *} . \quad \mid$ & $1^{*} \cdot i$ & 60.212 & 0.072 & 30.454 & 0.000 \\
\hline $1^{*} . \quad \mid$ & 1.1 & 70.146 & 0.015 & 31.346 & 0.000 \\
\hline $1^{*}$ & 1 & 80.129 & 0.017 & 32.069 & 0.000 \\
\hline $1^{*} \cdot 1$ & i. i & 90.131 & 0.032 & 32.851 & 0.000 \\
\hline$\left.\right|^{*}$ & 1. 1 & 100.085 & 0.011 & 33.194 & 0.000 \\
\hline $.1^{*} \cdot 1$ & 1.1 & 110.084 & 0.025 & 33.552 & 0.000 \\
\hline & & & - & & \\
\hline & & 120.046 & 0.074 & 33.666 & 0.001 \\
\hline & | & 130.016 & 0.009 & $33.67 \leqq$ & 0.001 \\
\hline$\cdot 1 \cdot 1$ & |. I & 140.031 & 0.023 & 33.739 & 0.002 \\
\hline 1 & 1. 1 & 150.000 & 0.035 & 33.739 & 0.004 \\
\hline 1.1 & 1.1 & 160.000 & 0.010 & 33.739 & 0.006 \\
\hline
\end{tabular}




\section{Correlogram of 'LnNPF'}

At First Difference

Date: 11/18/09 Time: 09:49

Sample: 2007M01 2009M06

Included observations: 29

\begin{tabular}{|c|c|c|c|c|c|}
\hline Autocorrelation & $\begin{array}{c}\text { Partial } \\
\text { Correlation }\end{array}$ & AC & PAC & $\begin{array}{l}\text { Q- } \\
\text { Stat }\end{array}$ & Prob \\
\hline${ }^{* * * *}|\cdot|$ & ${ }^{* * * *}|\cdot|$ & 10.462 & 0.462 & 6.8617 & 0.009 \\
\hline$\left.\cdot \cdot^{* *}|\cdot|\right|^{* \star * * *} \mid$ & $\frac{{ }^{* * * *} \mid}{\left.\cdot\right|^{* *} \cdot \mid} \mid$ & $\begin{array}{ll}2 & 0.285 \\
3 & 0.639\end{array}$ & $\begin{array}{l}0.634 \\
0.277\end{array}$ & $\begin{array}{l}9.5688 \\
23.673\end{array}$ & 0.008 \\
\hline${ }^{* * *}|\cdot|$ & $.1 \cdot 1$ & 40.376 & 0.003 & 28.754 & 0.000 \\
\hline$\cdot{ }^{*}|\cdot|$ & $\cdot{ }^{*}|\cdot|$ & 50.184 & 0.117 & 30.021 & 0.000 \\
\hline$\left.\cdot\right|^{* * *} \mid$ & $\cdot{ }^{* *}|\cdot|$ & 60.385 & 0.204 & 35.825 & 0.000 \\
\hline${ }^{*} \mid .1$ & $1^{*} \cdot 1$ & 70.138 & 0.135 & 36.602 & 0.000 \\
\hline${ }^{*}|\cdot|$ & $\left.\right|^{* *} \cdot \quad \mid$ & 80.082 & 0.275 & 36.891 & 0.000 \\
\hline $1^{*} \cdot 1$ & ${ }^{*}|\cdot|$ & $\begin{array}{r}90.078 \\
\text { - }\end{array}$ & 0.138 & 37.163 & 0.000 \\
\hline 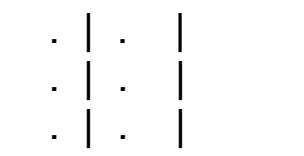 & 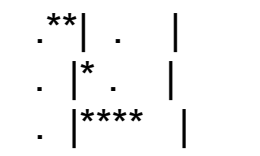 & $\begin{array}{ll}10 & 0.020 \\
11 & 0.024 \\
12 & 0.004\end{array}$ & $\begin{array}{l}0.262 \\
0.080 \\
0.464\end{array}$ & $\begin{array}{l}37.182 \\
37.212 \\
37.213\end{array}$ & $\begin{array}{l}0.000 \\
0.000 \\
0.000\end{array}$ \\
\hline
\end{tabular}


$\mathrm{NPL}_{t}=c+\mathrm{NPL}_{t-1}+\theta \operatorname{Spread}_{t-1}+\beta T_{t-1}+\mu_{t}$

Vector Auto regression Estimates

Date: 11/18/09 Time: 09:44

Sample (adjusted): 2007M03

2009M06

Included observations: 28 after

adjustments

Standard errors in ( ) \& t-statistics

in [ ]

\begin{tabular}{lr}
\hline \hline & \multicolumn{1}{c}{ LNNPF } \\
\hline \hline LNNPF(-1) & $\begin{array}{r}0.526873 \\
(0.17989)\end{array}$ \\
& {$\left[\begin{array}{l}2.92892] \\
\text { LNNPF(-2) }\end{array}\right.$} \\
& 0.447700 \\
& $(0.18501)$ \\
& {$[2.41987]$} \\
& \\
& 0.309152 \\
& $(0.77917)$ \\
& {$[0.39677]$} \\
\hline \hline R-squared & 0.759419 \\
Adj. R-squared & 0.740172 \\
Sum sq. resids & 4.302152 \\
S.E. equation & 0.414833 \\
F-statistic & 39.45751 \\
Log likelihood & -13.50703 \\
Akaike AIC & 1.179073 \\
Schwarz SC & 1.321810 \\
Mean dependent & 7.186259 \\
S.D. dependent & 0.813823 \\
\hline \hline
\end{tabular}

